\title{
Amlodipine Vs. hydrochlorothiazide: is there any disparity in its antihypertensive effect or not?
}

\author{
Venu Gopal Jonnalagadda ${ }^{1 *}$ D, Kanchan Choudhary $^{2}$ and Vijay Kranti Matety ${ }^{1}$
}

\begin{abstract}
We have read the article "Comparison of effects between calcium channel blocker and diuretics in combination with angiotensin II receptor blocker on 24-h central blood pressure and vascular hemodynamic parameters in hypertensive patients: study design for a multicenter, double-blinded, active controlled, phase 4, randomized trial" by GC Oh., et al. and found it quite interesting to learn the testing of effectiveness between amlodipine and hydrochlorothiazide in combination with losartan. After 4 weeks of therapy, non-responders were exposed for dose titration of losartan/ amlodipine 100/5 mg daily or losartan/hydrochlorothiazide 100/25 mg daily. However, authors didn't increase in the amlodipine dose from 5 to $10 \mathrm{mg}$ from randomization. However, as per literature both drugs are non-significant in their blood pressure lowering effect. The clarification on above point will further allay the efficacy concerns of clinicians and result in wider usage of future published data.
\end{abstract}

Keywords: Hypertension, Calcium channel blockers, Thiazide diuretics, ARB blockers

\section{Dear Editor,}

We have read the article "Comparison of effects between calcium channel blocker and diuretics in combination with angiotensin II receptor blocker on 24-h central blood pressure and vascular hemodynamic parameters in hypertensive patients: study design for a multicenter, double-blinded, active controlled, phase 4 , randomized trial" by GC Oh., et al. and found it quite interesting to learn the testing of effectiveness between amlodipine and hydrochlorothiazide in combination with losartan [1].

In study design, the authors presented that, patients will undergo 4 weeks open labeled run in period followed by eligible patients randomized to either losar$\tan /$ amlodipine $50 / 5 \mathrm{mg}$ daily or losartan/ hydrochlorothiazide 50/12.5 mg daily for those who are having mean sitting systolic blood pressure (msSBP) $\geq 140 \mathrm{mmHg}$. After 4 weeks of therapy, non-responders were exposed for dose titration of losartan/amlodipine 100/5 mg daily

\footnotetext{
* Correspondence: gopalvenu63@gmail.com

'Department of Pharmacology \& Toxicology, National Institute of

Pharmaceutical Education and Research, Bhangagarh, Guwahati, Assam

781006, India

Full list of author information is available at the end of the article
}

or losartan/hydrochlorothiazide 100/25 mg daily. However, authors didn't increase in the amlodipine dose from 5 to $10 \mathrm{mg}$.

In the $\mathrm{AB}$ Adolphe et al., at the end of week 12, the mean reductions for supine and standing systolic and diastolic blood pressure values with amlodipine 2.5 to $10 \mathrm{mg}$ were $-15.2 /-12.3 \mathrm{mmHg}$ and $-14.0 /-11.6 \mathrm{mmHg}$ respectively, as compared to $-15.5 /-11.1 \mathrm{mmHg}$ and $-16.1 /-10.1 \mathrm{mmHg}$ after treatment with hydrochlorothiazide25-100 mg with comparable efficacy between both groups [2]. In another study presented by Tanaka $\mathrm{N}$ et al., amlodipine and hydrochlorothiazide decreased both systolic and diastolic blood pressure in both groups, but didn't show any significant difference between both arms after 8 weeks [3].

After analyzing the above data from the study by GC Oh et al.; it was spotted that escalating the dose in one arm cannot signify its superiority over the other. Here in this study the dose for hydrochlorothiazide was escalated from 12.5 to $25 \mathrm{mg}$ whereas the dose for amlodipine lingered same i.e. $5 \mathrm{mg}$.

Published literatures worldwide are of great help for physicians in going ahead to improve their prescription writing. Their baskets of knowledge are enhanced by these basic findings and hence without maintaining a 
parallel relationship between the two arms, it will not be reasonable to conclude the superiority of losartan/hydrochlorothiazide over losartan/ amlodipine.

The clarification on above point will further allay the efficacy concerns of clinicians and result in wider usage of future published data.

\section{Acknowledgements}

The authors would like to thank to almighty and parents for their support.

\section{Funding}

There is no funding for this work.

Availability of data and materials

There is no supporting data for this publication.

\section{Authors' contributions}

VG conceptualizes the idea and KC and VK prepared the manuscript with their technical acumen. All authors read and approved the final manuscript.

Ethics approval and consent to participate

Not applicable

\section{Consent for publication}

Not applicable

\section{Competing interests}

The authors declare that they have no competing interests.

\section{Publisher's Note}

Springer Nature remains neutral with regard to jurisdictional claims in published maps and institutional affiliations.

\section{Author details}

'Department of Pharmacology \& Toxicology, National Institute of Pharmaceutical Education and Research, Bhangagarh, Guwahati, Assam 781006, India. 'Department of Pharmacology \& Toxicology, Bhupal Nobles' Institute Of Pharmaceutical Sciences, Udaipur, Rajasthan 313001, India.

Received: 6 November 2017 Accepted: 23 November 2017

Published online: 06 December 2017

\section{References}

1. GC O, Lee HY, Chung WJ, Youn HJ, Cho EJ, Sung KC, et al. Comparison of effects between calcium channel blocker and diuretics in combination with angiotensin II receptor blocker on 24-h central blood pressure and vascular hemodynamic parameters in hypertensive patients: study design for a multicenter, double-blinded, active-controlled, phase 4, randomized trial. Clin Hypertens. 2017;23:18.

2. Adolphe AB, Vlachakis ND, Rofman BA, Brescia D, Zellner SR. Long-term open evaluation of amlodipine vs hydrochlorothiazide in patients with essential hypertension. Int J Clin Pharmacol Res. 1993;13:203-10.

3. Tanaka N, Babazono T, Tanaka M, Shimada Y, Tomonaga O, Uchigata Y. Antihypertensive and metabolic effects of hydrochlorothiazide versus amlodipine when added to losartan in patients with type 2 diabetes. Diabetol Int. 2016;7:266-73

Submit your next manuscript to BioMed Central and we will help you at every step:

- We accept pre-submission inquiries

- Our selector tool helps you to find the most relevant journal

- We provide round the clock customer support

- Convenient online submission

- Thorough peer review

- Inclusion in PubMed and all major indexing services

- Maximum visibility for your research

Submit your manuscript at www.biomedcentral.com/submit 